\title{
THE EFFECTIVENESS OF COMPOST, HUMIC ACID AND PURE FULVATE ON IMPROVEMENT OF ULTISOL SOIL CHEMICAL PROPERTIES
}

\author{
$\operatorname{Resman}^{1}$ \\ ${ }^{1}$ Agricultural Doctoral Student, Postgraduate, \\ Universitas Halu Oleo, \\ Kampus Kemaraya, Kendari, \\ Southeast Sulawesi, 93121, Indonesia
}

\author{
Sahta Ginting ${ }^{2}$ \\ Department of Soil Science, \\ Faculty of Agriculture Universitas Halu Oleo, \\ Kampus Bumi Tridharma Anduonohu, \\ Kendari Southeast Sulawesi, 93232, Indonesia
}

\author{
Halim $^{5}$ \\ Department of Agrotechnology, \\ Faculty of Agriculture Universitas Halu Oleo, \\ Kampus Bumi Tridharma Anduonohu, \\ Kendari Southeast Sulawesi, Kendari, 93232, Indonesia
}

Article DOI: https://doi.org/10.36713/epra6996

DOI No: 10.36713/epra6996

\begin{abstract}
The research aimed to determine the effectiveness of compost containing humic and fulvic acids, and pure humic and fulvic acids in increasing of Ultisol soil chemical properties. The research design used a randomized block design (RBD), consisting of 10 treatments, namely K0: $0 \mathrm{~g}_{\text {polybag }}{ }^{-1}, \mathrm{KO1}: 500 \mathrm{~g} \mathrm{polybag}^{-1}$, KO2: $500 \mathrm{~g} \mathrm{polybag}^{-1}$, KO3: $500 \mathrm{~g} \mathrm{polybag}^{-1}$, KO4: $500 \mathrm{~g} \mathrm{polybag}^{-1}$, KO5: $500 \mathrm{~g} \mathrm{polybag}^{-1}$, KO6: $500 \mathrm{~g} \mathrm{polybag}^{-1}$, KO7: $500 \mathrm{~g} \mathrm{of} \mathrm{polybags}^{-1}$, H: $50 \mathrm{~g} \mathrm{of} \mathrm{polybag}^{-1}$, A: 500 g polybag-1. Each treatment was repeated three times and obtained 30 treatment units. The results showed that pH $\mathrm{H}_{2} \mathrm{O}$ (K0: 4.49, KO1: 5.64, KO2: 5.47, KO3: 5.43, KO4: 5.51, KO5: 5.39, KO6: 5.48, KO7: 6.17, H: 5.06, F: 5.15), total-N (\%) (K0: 0.13, KO1: 0.17, KO2: 0.18, KO3: 0.30, KO4: 0.25, KO5: 0.24, KO6: 0.29, KO7: 0.36, H: 0.16, F: 0.14), organic-C (\%) (K0: 1.85, KO1; 2.30, KO2: 2.24, KO3: 2.33, KO4: 2.62, KO5: 2.25, KO6: 2.27, KO7: 2.95, H: 2.32, F: 2.26) , available-P (\%) (KO: 2.75, KO1: 3.24, KO2: 3.16, KO3: 3.27, KO4: 3.57, KO5: 3.31, KO6: 3.37, KO7: 3.89, H: 3.10, F: 3.12), exchangeable-Al (me100g $\left.{ }^{-1}\right)$ (KO: 2.51, KO1: 2.11, KO2: 2.13, KO3: 2.15, KO4: 1.88, KO5: 2.14, KO6: 2.12, KO7: 1.75, H: 2.16, F: 2.17), base saturation (\%) (KO: 30.91, KO1: 63.48, KO2: 52.63, KO3: 53.76, KO4: 56.13, KO5: 54.96, KO6: 56.71, KO7: 65.53, H: 39.11, F: 42.76), cation exchange capacity (me100g $\left.{ }^{-1}\right)(\mathrm{KO}: 12.76, \mathrm{KO1}: 15.64, \mathrm{KO2:} 14.86$, KO3: 14.35, KO4: 14.13, KO5: 15.01, KO6: 15.50, KO7: 17.94, H: 14.19, F: 13.73). The combined compost treatment of three types of organic matter (Imperata cylindrica + Rice straw + Glincidia sepium) is more effective in increasing the $\mathrm{pH}, \mathrm{H}_{2} \mathrm{O}$ as $37.42 \%$, total- $\mathrm{N}$ as $176.92 \%$, Organic- $\mathrm{C}$ as $59.46 \%$, available-P as $41.45 \%$, base saturation as $65.53 \%$, cation exchange capacity as $17.94 \%$ and exchangeable -Al, Alreduction as $30.28 \%$ of ultisol soil.
\end{abstract}

KEY WORDS: compost, humic acid, fulvate, soil chemical, ultisol 


\section{INTRODUCTION}

Dry land in Indonesia is more than half of the land area or $78 \%$ of the land area, one of them is land with the Ultisol order. Ultisols are the largest suboptimal dry lands in Indonesia $(45,794,000$ ha) or about $25 \%$ of the total land area of Indonesia. Scattered in Kalimantan $(21,938,000$ ha), Sumatra (9,469,000 ha), Maluku and Papua $(8,859,000$ ha), Sulawesi $(4,303,000$ ha), Java $(1,172,000 \mathrm{ha})$, and Nusa Tenggara (53,000 ha) [1].

In Southeast Sulawesi, Ultisol land area reaches $22,997.29$ has the low level of soil fertility so that they are grouped into types of marginal soil with the characteristics: high acidity $\mathrm{pH} \mathrm{H}_{2} \mathrm{O}<5.0$, low nutrient content, high aluminum $(\mathrm{Al})$ toxicity, high phosphorus fixation, low cation exchange capacity, low organic matter and sensitive to erosion [2]. Al is mostly dissolved at $\mathrm{pH} \mathrm{H} 2 \mathrm{O}<5.0$ so that it is toxic to plant roots and in these conditions, $\mathrm{Al}$ binds to the nutrients Phosphorus which makes Phosphorus unavailable to plants. According to Ginting et al. [3], all toxicity and phosphorus fixation in ultisols are urgent problems that must be addressed to increase nutrient availability for plants. Phosphorus deficiency can negatively impact crop yields and, in conditions of severe deficiency, can lead to plant death [4]. The dissolution of $\mathrm{Al}$ in acidic soils can lead to $\mathrm{Al}$ toxicity towards plants depending on the species of $\mathrm{Al}$ present and can decrease crop yield [5].

To overcome this problem, it can be done by providing organic materials such as Imperata cilindrica, rice straw, and Gliricidia sepium. According to Zhao et al. [5], the application of different organic matter can be used to reduce $\mathrm{Al}$ toxicity, increase soil fertility and also increase crop yields. Imperata cilindrica organic matter contains $17.85 \%$ of lignin, $1.38 \%$ of total-N, $0.16 \%$, total-P, and $0.54 \%$, total-K, while rice straw contains $14.67 \%$ of lignin, $0.34 \%$ of total-N, $0.07 \%$ of total-P, and $1.39 \%$ total-K), and Gliricidia sepium contains $7.9 \%$ of lignin, $2.81 \%$ total-N, $0.26 \%$ total-P, and $0.94 \%$ total-K.

However, in the process of decomposition of organic matter that occurs naturally, it takes a long time. So that in this study we used Orgadec bio activator to accelerate the decomposition process. In addition to accelerating the composting process, the use of Orgadec bio activator can increase the quality of compost. The Orgadec dosage is $12.5 \mathrm{~kg}$ for every 1 ton of ingredients [6]. This bio activator is formulated with active ingredients use indigenous microbial such as fungi Trichoderma pseudokoningii and bacteria Cytophaga sp. which can rapidly reduce the $\mathrm{C} / \mathrm{N}$ ratio and are antagonistic to several types of root fungal diseases. They also have a high ability to produce lignin and cellulose-degrading enzymes simultaneously, so that the carbon content will decrease and the nitrogen content will increase and the $\mathrm{C} / \mathrm{N}$ become low.

The principle of composting is to reduce the
$\mathrm{C} / \mathrm{N}$ ratio of organic matter to or close to the soil $\mathrm{C} / \mathrm{N}$ ratio $(<20)$. Composting is an aerobic process, which requires optimal oxygen, moisture content, and porosity to stabilize organic matter, and is influenced by temperature, oxygen, and humidity [7]. Besides, microbial activity through complex metabolic processes are responsible for the fractional decomposition and humification (biological oxidative transformation) of organic matter, which turns it into a nutritious soil amendment, i.e. compost, a valuable stable, mature and contamination-free product for crop cultivation, and increases of soil fertility [8]. Microorganisms utilize carbon and nitrogen which are contained in organic matter as a source of energy in carrying out decomposition activities. The decomposition of organic matter in the soil will eventually leave humus. Humus or soil humus is an important part of organic matter content, which can be effectively increased with the application of straws [9]. Soil humus is mainly composed of soil humic acid (HA) and soil fulvic acid (FA). It is highly available in the soil, easily decomposed and mineralized by soil microbes, and directly affects nutrient supply in plants. It plays a key role in maintaining soil fertility, improving soil quality, and maintaining soil carbon pool balance [10].

The novelty of this research is the use of a combination of three types of organic matter such as reeds, rice straw, and gamal leaves as a basic material for composting which produces higher levels of nutrients, humic acid, and fulvic acid compared to other types of organic matter.

\section{MATERIALS AND METHODS Research Location and Time}

The research was done in Kambu Village, Kendari City, Southeast Sulawesi Indonesia was conducted for five months from May to September 2019.

\section{Experimental Setup}

The tools used in this study were hoes, machetes, scales, knives, cameras, polybags 30 $\mathrm{x} 40 \mathrm{~cm}$ in size, tarpaulin, sacks, plastic bags, laboratory equipment, and writing instruments. The materials used were Ultisol soil $5 \mathrm{~kg}$ polybag- $^{-1}$, compost $500 \mathrm{~g}^{\text {polybag- }}{ }^{-1}$, water, and chemicals. The research design used a randomized block design (RBD), consisting of 10 treatments, namely; control (0) $0 \mathrm{~g}$ polybags $^{-1}$, Orgadec compost + Imperata cilindrica (KO1), Orgadec compost + Rice straw (KO2), Orgadec compost + Gliricidia sepium (KO3), Orgadec compost + Imperata cilindrica + Rice straw (KO4), Orgadec compost + Imperata cilindrica + Gliricidia sepium (KO5), Orgadec compost + Rice straw + Gliricidia sepium (KO6), Orgadec compost + Imperata cilindrica + Rice straw + Gliricidia sepium (KO7), humic acid (AH) and pure fulvicc acid (AF). Each treatment was repeated three times to obtain 30 treatment units. Compost, pure humic acid, and pure 
fulvic acid for each treatment were mixed on the soil of the incubation media, thens put into the polybags that had been labeled, then doused with water until moist then incubated for 30 days.

\section{Research Variable}

The variable observed in Analysis compost of Humic Acid, Fulvic Acid, Compost $\mathrm{pH}$ and total$\mathrm{P}$, total-N, organic- $\mathrm{C}$, $\mathrm{C} / \mathrm{N}$ Ratio, Water Content Orgadec Bioactivator Treatment on Three Types of Organic Materials. So to Results of Analysis of the Effect of Compost, Humic Acid and Pure Fulvic of $\mathrm{pH}$ of $\mathrm{H}_{2} \mathrm{O}$, total- $\mathrm{N}$, organic-C, Humic Acid and Pure
Fulvic on available-P, exchangeable-Al, Base saturation and Cation Exchange Capacity in Ultisol soil incubated for 30 days.

\section{RESULTS}

Results of Analysis of Humic Acid, Fulvic Acid, compost $\mathrm{pH}$, total-P, total-N, organic-C, $\mathrm{C} / \mathrm{N}$ Ratio and Water Content Orgadec Bioactivator Treatment on Three Types of Organic Materials Table 1.

Table 1. Results of Analysis of Humic Acid, Fulvic Acid, compost pH, total-P, total-N, organic-C, C/N Ratio and Water Content Orgadec Bioactivator Treatment on Three Types of Organic Materials

\begin{tabular}{|c|c|c|c|c|c|c|c|c|}
\hline Treatment & $\begin{array}{c}\mathrm{AH} \\
\left(\mathrm{mg} \mathrm{g}^{-1}\right)\end{array}$ & $\begin{array}{c}\text { AF } \\
(\mathrm{mg} \mathrm{g} \\
1)\end{array}$ & $\begin{array}{c}\text { Compost } \\
\mathbf{p H}\end{array}$ & $\begin{array}{c}\text { total-P } \\
(\%) \\
\end{array}$ & $\begin{array}{c}\text { total-N } \\
(\%)\end{array}$ & $\begin{array}{c}\text { organic-C } \\
(\%)\end{array}$ & $\begin{array}{c}\mathrm{C} / \mathrm{N} \\
\text { ratio }\end{array}$ & $\begin{array}{c}\text { Water } \\
\text { Content } \\
(\%)\end{array}$ \\
\hline K01 & 46.34 & 199.38 & 7.14 & 1.60 & 0.99 & 20.05 & 20.25 & 15.23 \\
\hline KO2 & 43.00 & 194.09 & 7.17 & 0.93 & 0.97 & 20.11 & 20.73 & 15.19 \\
\hline KO3 & 35.76 & 175.45 & 7.24 & 1.51 & 1.43 & 20.96 & 14.65 & 15.65 \\
\hline KO4 & 44.80 & 187.32 & 7.14 & 0.97 & 1.17 & 19.09 & 16.32 & 16.15 \\
\hline KO5 & 39.26 & 180.95 & 7.23 & 1.49 & 1.24 & 22.49 & 18.14 & 16.46 \\
\hline K06 & 37.62 & 185.03 & 7.16 & 0.98 & 1.35 & 19.05 & 14.11 & 15.45 \\
\hline KO7 & 43.76 & 197.06 & 7.45 & 1.73 & 2.10 & 21.79 & 10.38 & 16.56 \\
\hline
\end{tabular}

compost $\mathrm{pH} ; \min .=6.80 ; \max .=7.49$

total-P; $\min .=0.10 \% ; \max .>0.10 \%$

total-N; $\min .=0.10 \% ; \max .>0.10 \%$

organic $-\mathrm{C} ; \min .=9.80 \% ; \max .=32 \%$

$\mathrm{C} / \mathrm{N}$ ratio; $\min .=10 ; \max .=20$

Max water content $=50 \%$

Results of Analysis of the Effect of total-N, organic-C in Ultisol Soil Incubated for 30 Compost, Humic Acid and Pure Fulvic of $\mathrm{pH}$ of $\mathrm{H}_{2} \mathrm{O}$, Days (Tables 2 and 3).

Table 2. Results of Analysis of the Effect of Compost, Humic Acid and Pure Fulvic of $\mathrm{pH}_{\mathrm{of}} \mathrm{H}_{2} \mathrm{O}$, total-N, organic-C in Ultisol Soil Incubated for 30 Days

\begin{tabular}{|c|c|c|c|c|c|c|}
\hline Treatment & $\mathrm{pH}\left(\mathrm{H}_{2} \mathrm{O}\right)$ & Criteria*) & $\begin{array}{c}\text { total-N } \\
(\%)\end{array}$ & Criteria*) & $\begin{array}{c}\text { organic-C } \\
(\%)\end{array}$ & Criteria*] \\
\hline K0 & 4.49 & M & 0.13 & $\mathrm{R}$ & 1.85 & $\mathrm{R}$ \\
\hline K01 & 5.64 & $\mathrm{AM}$ & 0.17 & $\mathrm{R}$ & 2.30 & S \\
\hline KO2 & 5.47 & M & 0.18 & $\mathrm{R}$ & 2.24 & $S$ \\
\hline K03 & 5.43 & M & 0.30 & $S$ & 2.23 & S \\
\hline K04 & 5.51 & M & 0.25 & S & 2.62 & S \\
\hline K05 & 5.39 & M & 0.24 & $S$ & 2.25 & $S$ \\
\hline K06 & 5.48 & M & 0.29 & $S$ & 2.27 & $S$ \\
\hline K07 & 6.17 & $\mathrm{AM}$ & 0.36 & $S$ & 2.95 & S \\
\hline $\mathrm{H}$ & 5.06 & M & 0.16 & $\mathrm{R}$ & 2.32 & $S$ \\
\hline $\mathrm{F}$ & 5.15 & M & 0.14 & $\mathrm{R}$ & 2.26 & S \\
\hline
\end{tabular}

AM: Sour, M: It's a little sour, S: Moderate, R: Low, H: Humic acid (50 g polybag-1), F: Fulvic acid (50 g polybag-1). 
EPRA International Journal of Multidisciplinary Research (IJMR) - Peer Reviewed Journal Volume: 7 | Issue: 5 | May 2021|| Journal DOI: 10.36713/epra2013 || SJIF Impact Factor 2021: 8.047 || ISI Value: 1.188

Table 3. The Effect of Compost, Humic Acid, and Pure Fulvic on the Increase in $\mathrm{pH}$ of $\mathrm{H}_{2} \mathrm{O}$, total-N and organic-C in Ultisol Soil Incubated for 30 Days

\begin{tabular}{|c|c|c|c|}
\hline \multirow{3}{*}{$\begin{array}{l}\text { Treatment } \\
\text { K01 }\end{array}$} & \multicolumn{3}{|c|}{ Changes in $\mathrm{pH} \mathrm{H}_{2} \mathrm{O}$, total- $\mathrm{N}$, and organic-C (\%) on the control } \\
\hline & pH Ho & total-N & organic-C \\
\hline & $25.61(+)$ & $30.77(+)$ & $24.32(+)$ \\
\hline KO2 & $21.83(+)$ & $38.46(+)$ & $21.08(+)$ \\
\hline K03 & $20.94(+)$ & $130.76(+)$ & $20.54(+)$ \\
\hline K04 & $22.72(+)$ & $92.31(+)$ & $41.62(+)$ \\
\hline K05 & $20.04(+)$ & $84.62(+)$ & $21.62(+)$ \\
\hline K06 & $22.05(+)$ & $123.08(+)$ & $22.70(+)$ \\
\hline KO7 & $37.42(+)$ & $176.92(+)$ & $59.46(+)$ \\
\hline $\mathrm{H}$ & $12.69(+)$ & $23.08(+)$ & $25.41(+)$ \\
\hline $\mathrm{F}$ & $14.70(+)$ & $7.69(+)$ & $22.16(+)$ \\
\hline
\end{tabular}

$(+)$ : Increase in $\mathrm{pH} \mathrm{H}_{2} \mathrm{O}(+)$ : Increase in total- $\mathrm{N}(+)$ : Increase organic-C

The results of the analysis of the effect of compost, humic acid, and pure fulvic against available-P, base saturation, cation exchange

capacity, and exchangeable-Al on Ultisols incubated for 30 days are presented in Tables 4 and 5 .

Table 4. Results of Analysis of the Effect of Compost, Humic Acid and Pure Fulvic on available-P, exchangeable-Al, Base Saturation and Cation Exchange Capacity in Ultisol Soil Incubated for 30 Days

\begin{tabular}{|c|c|c|c|c|c|c|c|}
\hline Treatment & $\begin{array}{c}\text { available- } \\
\mathbf{P} \\
(\%)\end{array}$ & $\mathbf{K}^{*}$ ) & $\begin{array}{l}\text { exchangeabl } \\
\text { e-Al } \\
\text { (me } 100 \mathrm{~g}^{-1} \text { ) }\end{array}$ & $\begin{array}{c}\text { Base } \\
\text { Saturation } \\
(\%)\end{array}$ & $\mathbf{K}^{*}$ ) & $\begin{array}{c}\text { CEC } \\
\left(\mathrm{me100}^{-1}\right)\end{array}$ & $\mathbf{K}^{*}$ ) \\
\hline K0 & 2.75 & SR & 2.51 & 30.91 & SR & 12.76 & SR \\
\hline K01 & 3.24 & SR & 2.11 & 63.48 & $\mathrm{~T}$ & 15.64 & $\mathrm{R}$ \\
\hline KO2 & 3.16 & SR & 2.13 & 52.63 & $S$ & 14.86 & $\mathrm{R}$ \\
\hline KO3 & 3.27 & SR & 2.15 & 53.76 & $\mathrm{~S}$ & 14.35 & $\mathrm{R}$ \\
\hline KO4 & 3.57 & SR & 1.88 & 56.13 & $S$ & 14.13 & $\mathrm{R}$ \\
\hline K05 & 3.31 & SR & 2.14 & 54.95 & $\mathrm{~S}$ & 15.01 & $\mathrm{R}$ \\
\hline K06 & 3.37 & SR & 2.12 & 56.71 & $S$ & 15.50 & $\mathrm{R}$ \\
\hline K07 & 3.89 & SR & 1.75 & 65.53 & $\mathrm{~T}$ & 17.94 & $\mathrm{R}$ \\
\hline $\mathrm{H}$ & 3.10 & SR & 2.16 & 39.11 & SR & 14.19 & $\mathrm{R}$ \\
\hline $\mathrm{F}$ & 3.12 & SR & 2.17 & 42.76 & $\mathrm{R}$ & 13.73 & $\mathrm{R}$ \\
\hline
\end{tabular}

Note: T: High, S: Moderate, R: Low, and SR: Very low

Table 5. The Effect of Compost, Humic Acid and Pure Fulvic on the Increase of available-P, Base Saturation, CEC and exchangeable-Al Decrease of , on Ultisol Soil Incubated for 30 Days Changes in levels of available-P, exchangeable-Al, Base Saturatio, and CEC (\%) on

\begin{tabular}{llccc} 
Treatment & $\begin{array}{l}\text { control } \\
\text { available-P }\end{array}$ & exchangeable-Al & Base Saturation & CEC \\
\hline K01 & $17.82(+)$ & $15.94(-)$ & $105.37(+)$ & $22.57(+)$ \\
K02 & $14.91(+)$ & $15.14(-)$ & $70.27(+)$ & $16.46(+)$ \\
K03 & $18.91(+)$ & $14.34(-)$ & $73.92(+)$ & $12.46(+)$ \\
K04 & $29.82(+)$ & $25.1(-)$ & $81.59(+)$ & $10.74(+)$ \\
K05 & $20.36(+)$ & $14.74(-)$ & $77.77(+)$ & $17.63(+)$ \\
K06 & $22.55(+)$ & $15.54(-)$ & $83.47(+)$ & $21.47(+)$
\end{tabular}




\begin{tabular}{lllll} 
K07 & $41.45(+)$ & $30.28(-)$ & $112.00(+)$ & $40.59(+)$ \\
$\mathrm{H}$ & $12.73(+)$ & $13.94(-)$ & $26.53(+)$ & $11.21(+)$ \\
$\mathrm{F}$ & $13.45(+)$ & $13.54(-)$ & $38.34(+)$ & $7.60(+)$ \\
\hline
\end{tabular}

Notes: $(+)$ : Increased available-P, $(+)$ : Increased Base Saturation, (+):Increased CEC improvement, ():exchangeable -Al drop

\section{DISCUSSION}

\section{Compost}

\section{a. Compost pH}

The average $\mathrm{pH}$ of compost (Table 1) shows that the $\mathrm{pH}$ is neutral in the range (7.14 to 7.45). The $\mathrm{pH}$ is following the ideal compost $\mathrm{pH}$ based on Indonesian National Standard (SNI) No. 19.7030.2004 [11]. Ideally, the $\mathrm{pH}$ of the compost is due to the microorganisms in the Orgadec bio activator having the ability to perform renovations. The $\mathrm{pH}$ of the compost material is acidic at the beginning of ferments this is because acid-forming bacteria will lower the $\mathrm{pH}$ so that the compost is more acidic. Furthermore, microorganisms begin to convert inorganic nitrogen into ammonium so that the $\mathrm{pH}$ increases rapidly to become alkaline. Some of the ammonia is released or converted to nitrate and nitrate is denitrified by bacteria so that the $\mathrm{pH}$ of the bokashi becomes neutral [13].

\section{b. Compost Humic acid and fulvic acid}

The average humic acid and fulvic acid (Table 1) show that the Orgadec bio activator treatment with Imperata cylindrica organic matter had the highest humic acid (46.34 mg/g) and fulvic acid (199.38 $\mathrm{mg} / \mathrm{g}$ ). The high content of humic acid and fulvic acid is since the organic material used in composting is reeds leaves which contain high cellulose and lignin. According to Minardi [14], the more cellulose and lignin content in organic material, the more humic acid, and fulvic acid content are in line with the decomposition process of the organic material.

\section{c. Compost total-P}

The average total-P (Table 1) shows the treatment (Imperata cylindrica + Rice straw + Glincidia sepium) had the highest total-P content $(1.73 \%)$. The increase in total-P content is caused by the microorganisms in the Orgadec bio activator work faster so that the microorganism's metabolic process produced phosphate minerals. Kurniawan et al. [15], stated that the increase in phosphorus levels is thought to be the influence of the activity of microorganisms that convert glucose in organic matter into lactic acid so that the environment becomes acidic which causes phosphate bound in long chains to dissolve in organic acids produced by microorganisms.

\section{d. Compost total-N \\ The average of total-N (Table 1) shows treatment (Imperata cylindrica + Rice straw +}

Glincidia sepium) had a high total-N content of approximately $(2.1 \%)$. This is due to the faster the process of refurbishing, the total value of inorganic nitrogen in $\mathrm{NH}^{+}$and $\mathrm{NO}^{-}$- compounds as a result of the decomposition process of organic matter will also increase. The organic material source of nitrogen such as protein will first undergo the breakdown by microorganisms into amino acids known as the aminization process [15].

\section{e. Compost C-organic}

The average of organic-C (Table 1), showed that the average value of organic-C ranges from $19.09 \%-22.49 \%$. This value indicates the optimum compost range based on the Indonesian National Standard (SNI) No. 19-7030-2004 [11]. The optimal content of organic-C is due to the maximum work of the bio activator so that it can quickly reform the organic material. According to Kurniawan et al. [15], microorganisms break down carbon compounds as an energy source in carrying out the renovation process.

\section{f. Compost $\mathrm{C} / \mathrm{N}$ ratio}

The average $\mathrm{C} / \mathrm{N}$ ratio (Table 1 ) shows the values ranged from 10.38-20.73. The ideal range is based on the Indonesian National Standard (SNI) No. 19-7030-2004 [11]. The decrease in the $\mathrm{C} / \mathrm{N}$ ratio of the Orgadec bio activator is due to the microorganisms working optimally so that they quickly reformed the organic material, resulting in carbon loss due to $\mathrm{CO} 2$ evaporation as a result of overhauling the organic material in the compost pile. In general the total concentration of organic-C decreases gradually during the fermentation process, this is due to the release of carbon dioxide through the respiration of microorganisms [15].

\section{g. Compost Water content}

The average water content (Table 1) shows that the water content ranged from $15.19 \%-16.56 \%$. This range includes the minimum moisture content based on Indonesian National Standard (SNI) No. 19-70302004 [11]. The low water content is due to the microorganisms in the compost pile working effectively, causing high evaporation so that the water content in the compost will decrease. The decrease in water content in aerobic composting occurs because the water content in the compost material evaporates due to heat, stirring, and consumption of microorganisms to convert protein into nutrients needed by plants [16].

The nutrient content in pure humic acid $(\mathrm{H})$ is $\mathrm{P}_{2} \mathrm{O}_{5}(0.2-3.7 \%), \mathrm{K}_{2} \mathrm{SO}_{4}(0.6 \%), \mathrm{Na}(0.05-0.15 \%), \mathrm{S}$ 
(0.6-11\%), $\mathrm{Fe}_{2} \mathrm{O}(5.6 \%)$. The nutrient content of pure fulvic acid $(\mathrm{F})$ is $\mathrm{P}_{2} \mathrm{O}_{5}(0.37 \%), \mathrm{K}_{2} \mathrm{O}(1.2 \%), \mathrm{C}$ organic (22-41\%), S (1.9\%), Fe (3947\%), Mn (57 ppm), $\mathrm{Cu}(16 \mathrm{ppm})$.

\section{Soil chemical a. $\mathrm{pH} \mathrm{H}_{2} \mathrm{O}$}

Tables 3 and 4 show that the treatment of compost, humic acid, and pure fulvic increased the $\mathrm{pH}$ of $\mathrm{H}_{2} \mathrm{O}$ by $(12.69 \%$ to $37.42 \%)$, with $\mathrm{pH}$ values ranging from (5.06 to 6.17). The high increase in $\mathrm{pH}$ $\mathrm{H}_{2} \mathrm{O}$ in the combined compost treatment of three types of organic matter (Imperata cylindrica + Rice straw + Glincidia sepium) is due to the organic matter that has been incubated in the decomposition process will release organic compounds, both in the form of organic acids and base cations, so that can suppress the activity of Al. The nutrient content given from organic matter in the soil is correlated with the length of the mineralization process required by organic matter to provide nutrients for the soil. Organic acids as a result of decomposition can bind $\mathrm{H}^{+}$ions as a cause of acidity in the soil so make the soil $\mathrm{pH}$ increases. Organic acids can bind $\mathrm{H}^{+}$ions through carboxyl groups which have a negative charge [17]. Furthermore, Bayer et al. [18], stated that the rise and fall of soil $\mathrm{pH}$ is a function of $\mathrm{H}^{+}$and $\mathrm{OH}^{-}$ions, if the concentration of $\mathrm{H}^{+}$ions in the soil solution increases, the soil $\mathrm{pH}$ will decrease, and if the $\mathrm{OH}^{-}$ion concentration increases, the soil $\mathrm{pH}$ will increase. Also, the increase in $\mathrm{pH} \mathrm{H}_{2} \mathrm{O}$ in the combined compost treatment of three types of organic matter (Imperata cylindrica + Rice straw + Glincidia sepium) had a $\mathrm{C} / \mathrm{N}$ ratio of 10.38 which was lower than the other treatments. The low $\mathrm{C} / \mathrm{N}$ ratio value will easily decompose which in turn will release the bases contained by the organic material.

\section{b. total-N}

Tables 3 and 4 show that the treatment of compost, humic acid, and pure fulvic increased the total-N value by $(7.69 \%$ to $176.92 \%)$, with total-Nvalues ranging from $(0.14 \%$ to $0.36 \%)$. Compost treatment from a combination of three types of organic matter (Imperata cylindrica + Rice straw + Glincidia sepium) can increase the N-total by $176.92 \%$. Meanwhile, fulvic acid treatment increased the lowest $\mathrm{N}$-total of about $7.69 \%$ with a total $\mathrm{N}$ value of $0.14 \%$. The increase in total-N in the combined compost treatment of three types of organic matter (Imperata cylindrica + Rice straw + Glincidia sepium) but still in the criteria (moderate). This is due to the lack of incubation time so that the organic matter has not been completely decomposed into soil organic matter (humus), besides that the total-N in the compost is partially lost due to evaporation (volatilization) and leaching (leaching) because total- $\mathrm{N}$ is easily transformed. In addition to the addition of soil nitrogen through the biological fixation of $\mathrm{N}_{2}$ (gas) from ammonia $\left(\mathrm{NH}_{3}\right)$ and nitrate
$\left(\mathrm{NO}_{3}\right)$, nitrogen compounds can also be lost through washing and volatilization [19].

\section{c. organic-C}

Tables 3 and 4show that the treatment of compost, humic acid, and pure fulvic increased the organic-C value by $(20.54 \%$ to $59.46 \%)$, with organic-C values ranging from $(1.85 \%$ to $2.95 \%)$. Compost treatment of three types of organic matter (Imperata cylindrica + Rice straw + Glincidia sepium) increased organic-C by about $50.46 \%$ compared to the control with a organic-C value of $2.95 \%$. While the compost treatment of gamal leaf organic matter increased the organic-C around $20.54 \%$ lower than other treatments with a organic-C value of $2.23 \%$. Lack of incubation time so that the compost that is applied in the soil becomes very slow to decompose so that the organic-C is still high. Organic matter content is influenced by the accumulation of native organic matter, decomposition, and humification. The decomposition of organic matter is much more important than the amount of organic matter added. Also, the increase in organic-C is the result of further decomposition of the given organic matter which can add to the organic matter in the soil.

\section{d. available-P}

Tables $3 \mathrm{a}$ and $3 \mathrm{~b}$ show that the treatment of compost, humic acid, and pure fulvic increased the available-P value by $(12.73 \%$ to $41.45 \%)$, with the available-P values ranging from (3.10 ppm to 3.89 ppm). Compost treatment of three types of organic matter (Imperata cylindrica + Rice straw + Glincidia sepium) can increase the available-P by about $41.55 \%$ compared to the control, with a available-P value of $3.89 \mathrm{ppm}$. Meanwhile, humic acid treatment increased the available-P $-12.73 \%$ lower. The high increase in available available-P compost treatment of combined three types of organic matter (Imperata cylindrica + Rice straw + Glincidia sepium) was due to the compost treatment of combined organic matter containing a total-P of $1.73 \%$ (Table 1). The high total- content in the compost will contribute more to the total P-content in the soil. The increase in available-P is also due to the decomposition of organic matter which produces organic acids which play a role in chelating $\mathrm{Al}$, thereby increasing the availability of Phosphorus in the soil. According to Gusnidar et al. [20], the incubation process of organic matter treatment will undergo a decomposition process, so that it will produce organic acids. Siregar et al. [17], also states that the increase in Phosphorus occurs due to the formation of complex $\mathrm{Al}$ compounds by decomposition of organic acids which can reduce the exchangeable-Al content and reduce the absorption of Phosphorus by $\mathrm{Al}$ so that the availability of Phosphorus increases. The increase in available-P due to the application of compost because of the effect of compost as an organic material on the 
availability of soil phosphorus that can occur directly through the mineralization process or indirectly with the help of the release of fixed phosphorus.

\section{e. exchangeable-Al}

Tables $3 \mathrm{a}$ and $3 \mathrm{~b}$ show that the treatment of compost, humic acid, and pure fulvic decreased the exchangeable-Al value by $(13.54 \%$ to $30.28 \%)$. exchangeable-Al values ranged from $\left(1.75 \mathrm{me} 100 \mathrm{~g}^{-1}\right.$

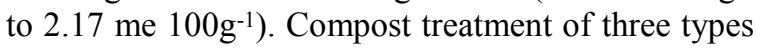
of organic matter (Imperata cylindrica + Rice straw + Glincidia sepium) can reduce exchangeable-Al by about $30.28 \%$ compared to control, with the exchangeable-Al value reaching 1.75 me $100 \mathrm{~g}-1$. Meanwhile, the fulvic acid treatment decreased exchangeable-Al by $13.54 \%$ at the lowest. The high reduction of exchangeable-Al in the compost treatment of the combination of three types of organic matter (Imperata cylindrica + Rice straw + Glincidia sepium) was due to the compost treatment of a combination of organic matter (Imperata cylindrical + Rice straw + Glincidia sepium) in compost having a $\mathrm{C} / \mathrm{N}$ ratio. the lowest is around 10.71 in (Table 1), so that organic matter will decompose more quickly in the soil and produce organic acids that form chelate compounds with free $\mathrm{Al}^{3+}$ in the soil so that $\mathrm{Al}^{3+}$ can be exchanged and there is a relationship between exchangeable- $\mathrm{Al}$ against $\mathrm{pH}$ of $\mathrm{H}_{2} \mathrm{O}$ and available- $\mathrm{P}$ soil. This is because $\mathrm{Al}^{3+}$ is a metal that can bind the element Phosphorus and make the soil $\mathrm{pH}$ acidic, this can be seen from the following reaction:

$$
\begin{gathered}
\mathrm{AB}^{+}+\mathrm{H}_{2} \mathrm{PO}^{4-+}+2 \mathrm{H} 2 \mathrm{O} \rightarrow 2 \mathrm{H}^{+}+\mathrm{Al}(\mathrm{OH}) 2 \mathrm{H} 2 \mathrm{PO} 4 \\
\text { Soluble }
\end{gathered}
$$

The more $\mathrm{Al}^{3+}$ ions that undergo hydrolysis, the more $\mathrm{H}^{+}$ions are donated and the more acidic the soil becomes. The decrease in the amount of exchangeable-Al due to the addition of compost, humic acid, and pure fulvic in the soil can increase the amount of phosphorus available and the soil $\mathrm{pH}$ will rise. [17] states that with an increase in humic acid dosage, there is also an increase in humic acid functional groups so that they can form complexes through carboxyl $(\mathrm{COOH})$ and phenolic $(\mathrm{OH})$ functional groups with $\mathrm{Al}^{3+}$ in amounts. which is quite a lot. As a result, the $\mathrm{Al}^{3+}$ that can be exchanged is reduced.

\section{Base Saturation}

Tables 4 and 5show that the treatment of compost, humic acid, and pure fulvic increased the base saturation value by $(26.53 \%$ to $112 \%)$, with base saturation values ranging from (39.11\% to $65.53 \%)$. Combined compost treatment of three types of organic matter (Imperata cylindrica + Rice straw + Glincidia sepium) can increase base saturation by about $112 \%$ compared to control with base saturation value reaching $65.53 \%$ criteria (high) higher when compared to other treatments. Meanwhile, humic acid treatment increased base saturation by $26.54 \%$.
The high value of base saturation in the combined compost treatment of three types of organic matter (Imperata cylindrica + Rice straw + Glincidia sepium) is due to the cation exchange which is dominated by alkaline cations, besides the compost applied to the soil produces a soil $\mathrm{pH}$ of 6.17 which is slightly acidic, so Basic cations are more dominant than acid cations. With the increase in base cations in the soil, the uptake complex in the soil is filled with base cations so that the base saturation increases. Sembiring et al. [21], stated that in soils with low alkaline saturation, the uptake complex is more dominant filled with acid cations such as $\mathrm{H}+$ and $\mathrm{Al}+$ cations. Providing compost can increase alkaline saturation. This is because the compost contains $\mathrm{COOH}$ (carboxylate), $-\mathrm{OH}$ (phenolic), and $-\mathrm{C}=\mathrm{O}$ (carbonyl) which can give an additional negative charge to the soil. The - $\mathrm{COOH}$ (carboxylate) group will release $\mathrm{H}+$ which then $\mathrm{H}+$ will bind with other anions so that it can increase the base saturation.

\section{Cation exchange capacity}

Tables 4 and 5 show that the treatment of compost, humic acid, and pure fulvic increases the value of cation exchange capacity by $(7.60 \%$ to $40.59 \%$ ), with cation exchange capacity values ranging from 13.73 me $100 \mathrm{~g}^{-1}$ to $17.94 \mathrm{me}^{100 \mathrm{~g}^{-1}}$. Compost treatment of three types of organic matter (Imperata cylindrica + Rice straw + Glincidia sepium) can increase the cation exchange capacity by around $40.59 \%$ with a value of 17.94 me $100 \mathrm{~g}^{-1}$ criteria (moderate), this value is higher when compared to treatment other. While the fulvic acid treatment increased the cation exchange capacity to the lowest about $7.60 \%$. The high increase in the value of cation exchange capacity in the combined compost treatment of three types of organic matter (Imperata cylindrica + Rice straw + Glincidia sepium), contains humic acid $\left(36.76 \mathrm{mg} \mathrm{g}^{-1}\right.$ ) and fulvic acid (190.06 $\mathrm{mg} \mathrm{g}^{-1}$ ) (Table 1), thereby causing an increase in the negative charge on soil colloids. This negative charge comes from the carboxyl $(\mathrm{COOH})$ and hydroxyl $(\mathrm{OH})$ groups present in organic compounds. The presence of functional groups of organic compounds can produce several negative charges in soil colloids [17]. The $(\mathrm{COOH})$ and $(\mathrm{OH})$ group dissociation of organic compounds can increase the negative charge in the soil so that the soil cation exchange capacity increases [22].

\section{CONCLUSION}

Combined compost treatment of three types of organic matter (Imperata cylindrica + Rice straw + Glincidia sepium) is more effective in increasing the $\mathrm{pH}$ of $\mathrm{H}_{2} \mathrm{O}$ by $37.42 \%$, total- $\mathrm{N}$ of $176.92 \%$, organicC by $59.46 \%$, available-P at $41.45 \%$, base saturation of $65.53 \%$, cation exchange capacity of $17.94 \%$ and exchangeable-Al reduction of $30.28 \%$ on Ultisol soil. 


\section{REFERENCES}

1. Gusnidar, Fitri A and Yasin S (2019) J. Solum Titonia and rice straw which are compressed on soil chemistry and corn production on ultisol. 16(1):11-18.

DOI: https://doi.org/10.25077/jsolum.16.1.1118.2019

2. Ginting $S$ (2007) Dry Land Development Towards Sustainable Agriculture in Southeast Sulawesi. Professor Inauguration Speech, Department of Agricultural Cultivation, Faculty of Agriculture, Halu Oleo University. March 24, 2007.

3. Ginting S, Johnson BB and Wilkens $S$ (1998) Alleviation of Aluminium Phytotoxicity on Soybean Growth by Organic Anions in Nutrient Solutions. Aust. J. Plant Physiol., 25: 901-908.

4. Dixon $M$, Simonne $E$, Obreza $T$ and Liu $G$ (2020) Crop Response to Low Phosphorus Bioavailability with a Focus on Tomato. Agronomy 2020, 10: 617. doi:10.3390/agronomy10050617

5. Zhao W, Li J, Jiang J, Lu H, Hong Z, Qian W, Xu $R$, Deng $K$ and Guan $P(2020)$ The mechanisms underlying the reduction in aluminum toxicity and improvements in the yield of sweet potato (Ipomoea batatas L.) After the organic and inorganic amendment of an acidic ultisol. Agriculture, Ecosystems \& Environment, 288: 106716

https://doi.org/10.1016/j.agee.2019.106716

6. Goenadi DH and Away Y (2009) Organic decomposer (Orgadec). Balai Penelitian Biotek Perkebunan Indonesia.

7. Roman P, Martinez MM and Pantoja A (2015) Farmer's Compost Handbook: Experiences in Latin America. Composting parameters and compost quality: A literature review. Org. Agric. 8: 141-158.

8. Sánchez ÓJ, Ospina DA and Montoya S (2017) Compost supplementation with nutrients and microorganisms in the composting process. Waste Manag., 69: 136-153.

9. Yanagi $Y$ and Shindo $H$ (2016) Assessment of long-term compost application on physical, chemical, and biological properties, as well as fertility, of soil in a field subjected to double cropping. Agric. Sci. 07: 30-43.

10. Chen X, Wu J and Opoku-Kwanowaa Y (2020) Effects of Returning Granular Corn Straw on Soil Humus Composition and Humic Acid Structure Characteristics in Saline-Alkali Soil. Sustainability, 12 : 1005. doi:10.3390/su12031005

11. National Standardization Body (2004) Compost Specifications from Domestic Organic Waste.SNI: 19-7030-2004. Jakarta.

12. Soil Research Institute (2009) Technical Guidelines for Chemical Analysis of Soil, Plants, Water, and Fertilizers. Agricultural Research and Development Agency of the Ministry of Agriculture.

13. Suwatanti $E$ and Widiyaningrum $P$ (2017) Utilization of Vegetable Waste MOL in Compost Making Process. Jurnal MIPA UNS, 4O(1): 1-6.

14. Minardi (2006) The Role of Humic and Fulvic
Acids from Organic Materials in the Release of Absorbed P in Andisols. Dissertation Summary. Postgraduate Program. Universitas Brawijaya. Malang. $21 p$

15. Kurniawan D, Kumalaningsih S and Sabrina NM (2016) The Effect of Addition Volume of Effective Microorganism $41 \%$ and Long Fermentation on the Quality of Bokashi Fertilizer from Rabbit and Jackfruit Waste. Jurnal Industria, 2(1):57-66.

16. Hadiwidodo M, Sutrisno E, Handayani DS and Febriani MP (2018) Study of Making Solid Compost from Dried Leaf Litter TPST UNDIP with a variety of local microorganism materials (MOL) leaves. Jurnal Presipitasi. Media Kumunikasi dan Pengembangan Teknik Lingkungan, 15(2): 78-85.

17. Siregar P, Fauzi and Supriadi (2017). Effect of Giving Several Sources of Organic Material and Incubation Period on Several Chemical Aspects of Ultisols Soil Fertility. Jurnal Agroteknologi FP USU, 5(2): 256-264.

18. Bayer C. Martin-Neto LP, Mielniczuk J, Pillon $C N$ and Sangoi L (2001) Changes in Soil Organic Matter Fractions Under Subtropical NoTill Cropping System. Soil Sci. Soc. Am.J., 65: 1473-1478.

19. Putra I and Jalil M (2015) The Effect of Organic Materials on Some of the Chemical Properties of Soil in Dry Acidic Soils, Agrotek Lestari, 1(1): 27-33.

20. Gusnidar, Hakim $N$ dan Prasetyo TB (2010) Incubation of Titonia in Rice Fields Against Organic Acids. Jurnal. Solum, 7(1): 7-18.

21. Sembiring IS, Wawan and Khoiri MA (2015) Chemical Properties of Soil Dystrudepts and Root Growth of Oil Palm Plants (Elasis guinensis Jacq) which Applied Organic Mulch. Jom Faperta, 2(2): 1-11.

22. Brady NC and Weil RR (2002) The Nature and Properties of Soils, 13th edition. Macmillan, New York. 683p. 